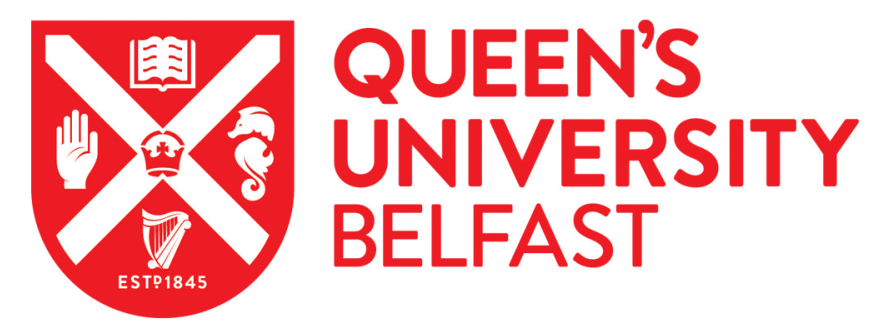

\title{
The Changing Context for Planning Education in the UK and the Prospects for Research-Led, Practice-Engaged Teaching
}

Ellis, G., Murtagh, B., \& Copeland, L. (2016). The Changing Context for Planning Education in the UK and the Prospects for Research-Led, Practice-Engaged Teaching. In A. Kumar, D. S. Meshram, \& K. Gowda (Eds.), Urban and Regional Planning Education: Learning for India (pp. 257-272). Springer. https://doi.org/10.1007/978981-10-0608-1_20

Published in:

Urban and Regional Planning Education: Learning for India

Document Version:

Peer reviewed version

Queen's University Belfast - Research Portal:

Link to publication record in Queen's University Belfast Research Portal

Publisher rights

@ 2016 Springer Science+Business Media Singapore

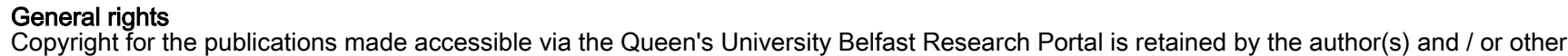
copyright owners and it is a condition of accessing these publications that users recognise and abide by the legal requirements associated with these rights.

Take down policy

The Research Portal is Queen's institutional repository that provides access to Queen's research output. Every effort has been made to ensure that content in the Research Portal does not infringe any person's rights, or applicable UK laws. If you discover content in the Research Portal that you believe breaches copyright or violates any law, please contact openaccess@qub.ac.uk. 
International Conference on Town and Country Planning Education:

Retrospect and Prospect

University of Mysore, India

21-23 November 2014

\title{
THE CHANGING CONTEXT FOR PLANNING EDUCATION IN THE UK AND THE PROSPECTS FOR RESEARCH-LED, PRACTICE-ENGAGED TEACHING
}

\author{
Geraint Ellis, Brendan Murtagh and Lisa Copeland \\ School of Planning Architecture and Civil Engineering \\ Queen's University Belfast, \\ David Keir Building \\ Stranmillis Rd, Belfast, BT9 5AG, UK \\ e-mail: g.ellis@qub.ac.uk \\ Twitter: @gellis23 \\ Tel: (+44) 2890974370
}

\begin{abstract}
The UK's Royal Town Planning Institute (RTPI) celebrates its centenary in 2014, marking 100 years of close relationships between university-based Planning Schools and a professional body focussed on planning practice. During this period, the context for university education and the very idea of planning has changed dramatically contributing to a continual renegotiation of the relationships between the planning profession and the educational institutions it accredits. These changes have been particularly acute in the last ten years where a number of factors have forced a rapid change in the nature of planning education in the UK. This has included a boom and then slump in the number of planning students linked to the national economic situation, a reorganisation of many planning schools and their merger with cognate disciplines such as geography and an increased focus of research output, rather than professional engagement the key institutional indicator of success. This last factor adds a particularly new dimension to the profession-university relationship, which could potentially lead to either a straining of tensions or a synergy through research-led teaching that could significantly benefit both.
\end{abstract}

This paper will briefly review the evolution of UK planning schools and the co-evolution of the main ideas informing planning education. It will then describe the current profile of UK planning schools, based on an extensive national survey conducted on behalf of the Royal Town Planning Institute. The paper will then critically review the main challenges and opportunities facing UK Planning Schools in the context of changes in both planning practice and higher education. It will then move on to the concept of research-led teaching, drawing on current practice in the UK and review how well this concept serves students and the idea of developing reflective planning practitioners. Finally, the paper will seek to draw broad lessons from the experience of the UK and reflect on the type of planning education that can best serve planning professions in a variety of international contexts in the future.

Key words: planning education; UK; research-led teaching 


\section{THE CHANGING CONTEXT FOR PLANNING EDUCATION IN THE UK AND THE PROSPECTS FOR RESEARCH-LED TEACHING}

\section{Introduction}

Planning education in the UK is now more than 100 years old, with the first British planning school launched in Liverpool University in 1909. Shortly after that, the Royal Town Planning Institute (RTPI) was formed in 2014, thus celebrating its centenary this year. The last century has seen the development of a close and interdependent relationship between university-based Planning Schools and a professional body focussed on planning practice. During this period, the context for university education and the very idea of planning has changed dramatically contributing to a continual renegotiation of the relationships between the planning profession and the educational institutions it accredits. Although this has been subject to evolution and change over time, major changes to UK universities, the funding of higher education and the governance of research activities over the last 15-20 years have changed the relationship with the planning profession in very fundamental ways. This paper briefly reviews some of these changes and provides a picture of current issues facing UK planning education, which may be shared by some Indian institutions. It particularly highlights the emphasis now placed on research in UK universities and explores whether this can be used to enhance the planning education and the broader links to the professional body.

\section{The profession and the academy: planning as a 'learned profession'?}

In claiming professional status, those involved in planning activity have sought to ensure that planning is seen not just as a routine administrative function for regulating land use, but an activity that involves attributes such as skilled, expert-based judgements and whose training requires an extended and specific period of study. Indeed, this is core to how the UK profession, in the form of the Royal Town Planning Institute (RTPI) has seen itself, not just as a profession (which has received critical comment, see Reade 1987, Evans 1995, Evans and Rydin 1997) but as a learned profession. Grant (1999) uses the term 'learned' specifically to draw comparisons with the established status of law, medicine and divinity and to emphasise learning and the advancement of an independent body of knowledge. In focussing on such aspects of the profession, Grant draws attention to the intellectual basis of planning, which clearly depends on close links to the planning academy and points to the fact that many practitioners (and, implicitly, the RTPI itself) misunderstand the role of planning schools, highlighting that:

"It is the duty of universities to educate their students, not to produce fully trained planners, and not to provide free training for the professions. It is their primary duty to enhance the intellectual and reflective capacity of their students, to develop their analytical and critical skills and to develop their capacity for further development." (p.7)

Despite this, Judge and Haughton (1998) suggested that the broader value of the planning academy has very much undervalued, noting that a survey of RTPI members indicated that academics were ranked bottom in terms of their influence as a main source of thinking about planning, compared to central and local government, professional organisations, the EU and the TCPA. This picture was also confirmed more recently by a survey by Ellis et al (2010). Indeed the tensions between education and practice, academia and the profession are a recurring theme in the academic literature and in the wider debates over planning education (e.g. Poxon 2001, Gurran et al 2006, Ozawa and Seltzer, 1999, Durning 2004, Dalton 2001, 2007). Campbell (2005) characterises the tension between practice and the academic community as being that the former values research in terms of its contribution to system maintenance, while the latter in terms of system transformation. As such, practitioners often view planning research as having irrelevance to the daily work of planners, while practice is criticised by academics for its lack of critical distance. Campbell (2005) thus highlights that practitioners fail to appreciate the changing and complex world in which planning academics now work, and Goodstadt (2005) suggests there may also be a lack of appreciation of practice by academics. Grant (1999) further comments that:

"The Institute's relations with the accredited schools is also something of a mixed experience. The accreditation process is sometimes (not always) seen by those at its receiving end as being negative in character, a dampener upon experimentation and innovation and an intrusion by 
However, it is not implied that there are no areas of convergence in the perception of academics and practitioners (Gurran et al 2006), nor are these particular to planning, with Griffiths (2004) suggesting that there are similar tensions in many built environment disciplines and in academia in general. Indeed, the RTPI has long recognised the competing pressures on academia and has long sought to encourage the wider intellectual development of the discipline through, for example, its association with the Annual Planning Research Conference, its recognition of the need for an active research culture in its definition of an "effective planning school" (RTPI 2004), the establishment of a Research and Knowledge Committee (formed in 2003), formed the Planning Education and Research Network (PERN) ${ }^{1}$, promotion of the Journal of Planning Theory and Practice and intermittent debates on the role of research in planning practice (e.g. Kitchen 1998). During its current centenary it has also prompted a range of deeper reflections on the nature and future of planning practice through its Horizon series ${ }^{2}$.

Despite this, the overall impression is that there are significant areas of tension in the academic-practice relationship (Poxon 2001) with professional planners under-valuing and even overlooking the repository of expert opinion residing on planning schools, which one could argue are central to advancing the independent knowledge of the planning field. Further tensions are introduced into academy-practice relationship when one considers the trajectory of development of planning schools and universities in the UK, which is explained in the next section.

\section{The Evolution of UK Planning Schools}

The detailed history of UK planning education and its close links with the evolution of planning have been presented elsewhere and will not be rehearsed here (e.g. Cockburn, 1970, Thomas and Thomas 1981, Healey 1983, Cherry 1974, Poxon 2001, Frank, 2006, Davoudi and Pendlebury 2014). In 1983 Healey characterised three phases of planning education:

- Pre-war (ie. Before 1939). This began with the first planning courses in 1909 to the establishment and bureaucratisation of the profession (Healey 1985) with the establishment of the comprehensive planning system. It is noted that the Town Planning Institute, formed in 1914, immediately concerned itself with educational matters by formulating a syllabus for professional exams and, particularly from the 1930 s onwards, encouraging the creation of more planning courses. Healey notes that '... planning courses were the children of the town planning movement, offering a mixed bag of architectural engineering and surveying techniques, coupled with ideals about the future of social organisation' (p. 4). Cherry (1974, p.222) describes this era as lacking innovation and a 'topping up' for those already qualified in a related discipline.

- 1947- to the mid-1960s. Healey (1983) notes this phase as being 'dominated by professional considerations', beginning with the new comprehensive UK planning system created in 1947 and a major review of planning education in the form of the Schuster report (1950). Planning education grew rapidly in the late 1960s, reflecting both the expansion of higher education and a renewed emphasis on planning as a policy tool. During this time we see the increasing presence of planning as a distinct discipline emphasising problem-solving, quantitative techniques and social science and a revised syllabus that stressed the academic status of planning courses. Until the 1960s planning schools were staffed almost exclusively by part-time staff and ex-practitioners (Thomas and Thomas 1981), which changed with the expansion of planning schools in the 1970s which saw for the first time, the appointment of staff with purely academic careers, drawn mostly from related disciplines of architecture, engineering and surveying.

\footnotetext{
${ }^{1}$ http://www.rtpi.org.uk/knowledge/research/planning-education-and-research-network/

2 http://www.rtpi.org.uk/knowledge/research/planning-horizons/about-planning-horizons/
} 
- Mid-1960s to 1980s. Healey (1983) notes that the professional considerations that dominated planning education in the 1970 s gave way to academic concerns, as funding agencies increasingly stressed academic criteria for course validation and funding. Indeed, Healey (1983) points to the emerging academic identity of planning schools expressed, through the activity of the Education Planning Association (founded in 1971), who saw themselves in partnership with the RTPI with a strong overlap in personalities. This phase marks a reduction in the influence of the RTPI over planning schools, as they strived to uphold academic values and a weakening of links to practice. Quoting Hague (1976) and Thomas (1979), Healey (1983) notes that it was during this period that control over the form and content of planning shifted away from the profession to the state. This was accompanied by a shift away from purely professional training to the teaching-research nexus, in essence marking the emergence of the distinct planning academy we have today.

It is possible to extend Healey's analysis to identify a further three phases since she completed her review:

- 1980s to late-1990s. This witnessed a period of retrenchment and pessimism within planning education, with falling student numbers and reduced funding for higher education. This period also saw the transformation of polytechnics into post-1992 universities, although the teaching-research polarisation between these and the older universities (noted by Healey above), has intensified with the introduction of the RAE ${ }^{3}$ in 1986, with consequences discussed below. Griffiths (2004) notes that this period also witnessed the closure of a number of planning schools.

- Late-1990s to 2010. This phase witnessed a re-establishment of the confidence of planning education and practice, epitomised by the RTPI's New Vision (2001) and Education Commission (2003). Student numbers increased substantially and in a context of prolonged economic growth demand for planning graduates outstripped supply and the skills required for practice shifted with the move towards the paradigm of spatial planning. This period has also seen a growing internationalisation of UK planning academia. There was an increase in the resources open to higher education, an improved funding regime for research and an increase in student numbers. Although the planning academy became more focused on research and knowledge production, Griffiths (2004) notes that, in the post-1992 universities at least, many staff still come into teaching on the basis of experience in practice, rather than as career academics.

- 2010 - Present day. The last four years has arguably see a further phase and retrenchment of planning education in the UK. Following collapse of the economy in 2008, job opportunities slumped and with it, student recruitment to planning courses. This was accompanied by the introduction of a new fees regime for university courses in the UK. The UK Government since 2010 has largely unsympathetic to the aims of the planning system and has dramatically cut public sector spending thus further restricting job opportunities for planning graduates. These forces have inevitably led to the closure of several planning schools and their merger with other disciplines, particularly geography, thus dramatically reducing the idea of planning as a distinct University based discipline.

Set against this context, Figures 1-4, complied from a variety of sources, indicate the evolution of planning education in terms of estimated student numbers, planning schools and numbers of courses, indicating a historic growth in the number of students, planning schools and programmes that reached a zenith in around 2008 , following which there has been a downturn in all these indicators.

\footnotetext{
${ }^{3}$ The Research Assessment Exercise was introduced in 1986 as a mechanism for evaluating research activity in the UK and as the basis for distributing research funding on a five year cycle. The RAE evolved in to the Research Excellence Framework. The last audit period ended at the end of 2013 and the results will be published in December 2014. See, for example Punter and Campbell (2009)
} 

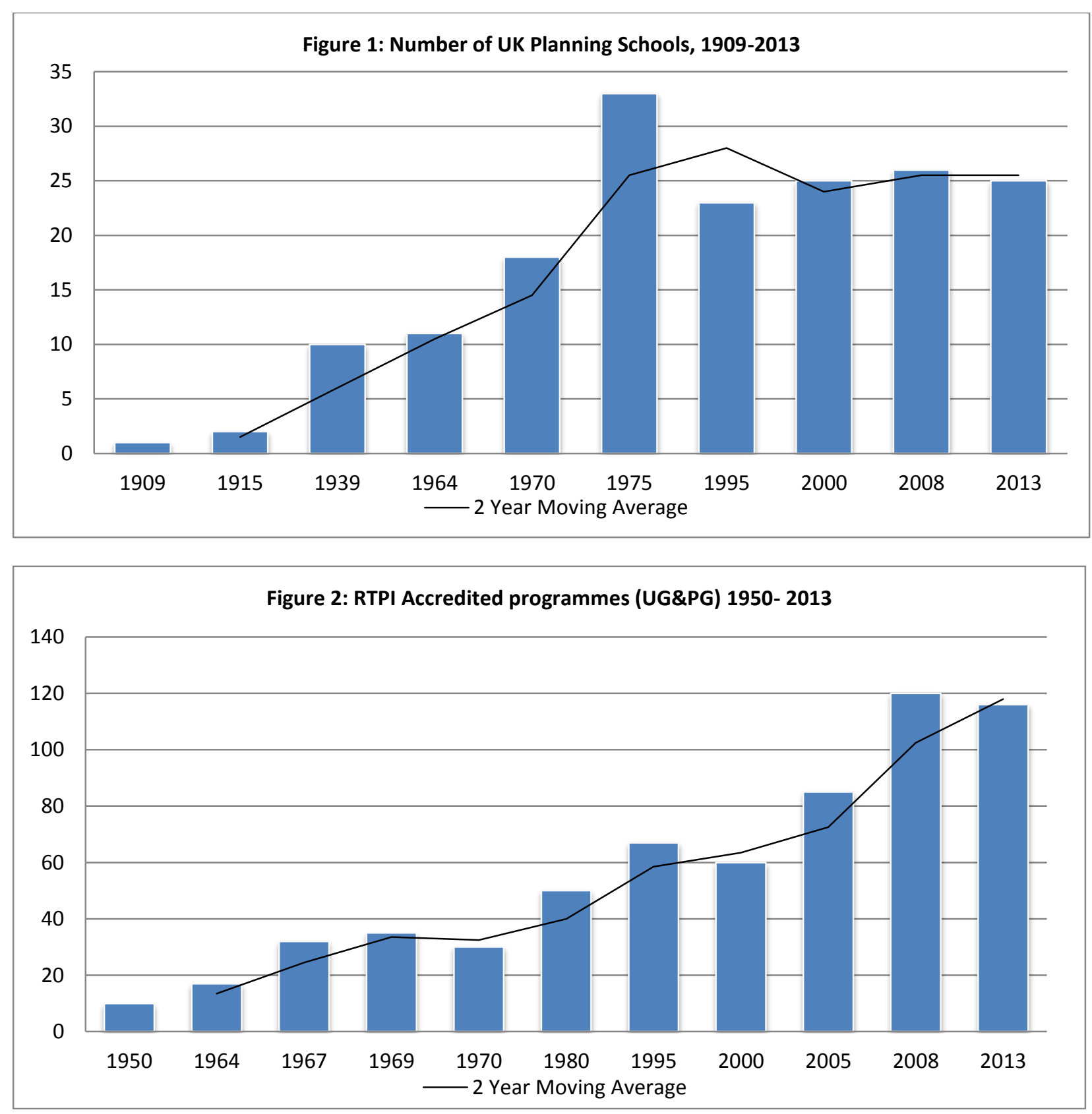

Figure 3: Enrolment on RTPI accrdited courses in the UK 2005-2013

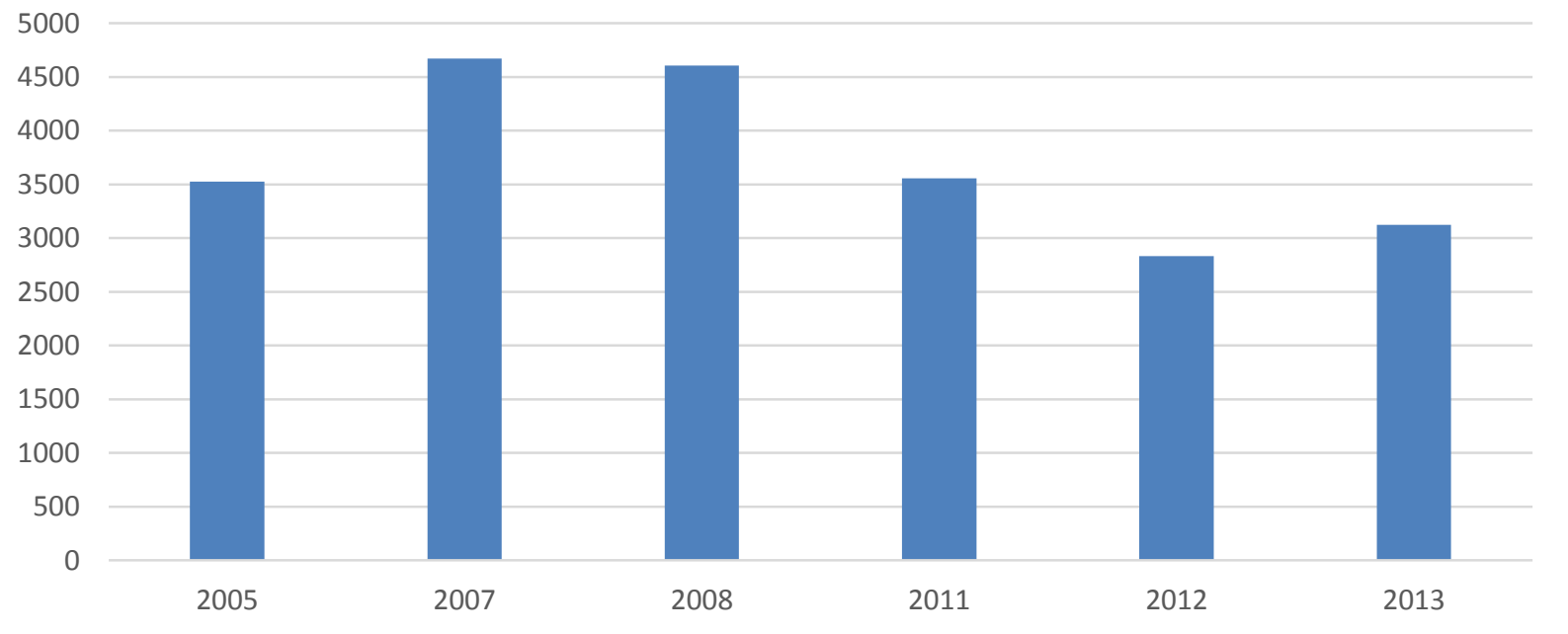


From the above, it becomes clear that the fortunes and confidence of the planning academy are closely related to the relative buoyancy of student numbers and have been strongly influenced by both the dynamics of higher education and those forces driving wider policies for higher education, the activities of the planning profession and broader context of planning practice. Indeed, UK universities have been subject to substantial changes stimulated by a dramatic expansion (up 35\%) since the mid-1990's, leading to a boom of academic recruitment in the early 2000s. The introduction of a fees regime has also further marketised universities and introduced a new degree of competition between and within universities, at a time when planning courses have not been well placed to highlight employment opportunities. Indeed, in such a context various league tables produced by leading newspapers (The Times, Guardian) become influential and draw extensively on insights to student experiences gathered as part of the National Student Survey ${ }^{4}$. There has also been increasing internationalisation of the UK student body as UK universities have gone to great lengths to recruit students from all parts of the world. Furthermore, following the introduction of the RAE/REF (see above), universities also expect planning schools to be centres of research and this is competitively reviewed every five or so years, with consequences for poor performing schools. $63 \%$ of planning student are studying in schools that have the highest research rating $\left(4^{*}\right)$ Universities place a great emphasis on the status of research units, so this is often seen as the priority for career advancement of academic staff, leading to further tensions with teaching activity. As a result there have been rapidly declining opportunities for practitioners to contribute to planning schools by transferring to an academic post. It has been suggested that as a result, in the next 10 years many planning schools may struggle to have any professionally accredited staff (Ellis et al 2010).

From this brief description of the evolution and current context for planning education, it should be clear that UK universities, and the planning schools they host, face a wide variety of changing external pressures with the professional orientation of their programmes having a relatively small influence on their future direction. Thus, while the RTPI and its powers of accreditation were once perhaps the key influence on university based planning schools and while this continues to have a strong influence, since the 1980s the University sector has been subject to a far greater range of influences that have tended to dilute links between the academy and the profession, leading to further sources of tension in this relationship.

These shifts have given rise to a number of tensions in many planning schools over content, method and even basic purpose of planning education: with some seeing it as primarily a vocational pursuit, some a others as a more general educational experience and others a higher academic discipline linked to original knowledge production. There has also been debate over whether the changes in education have led to a less engaged student body and the ability of staff to be both excellent teachers (measured in the NSS) and outstanding researchers. Thus Thomas (2005) has noted that "...there is a malaise in university planning education in the UK, other manifestations of which include a growing inability to recognise and support what might constitute intellectual achievement ... and a de-sensitisation to important aspects of student development that is directly linked to too much attention being devoted to teaching techniques and measurable 'learning outcomes'." (p.238).

\section{Current Planning Education in the UK}

This evolution has resulted in a UK planning education sector currently in 25 professionally-accredited university planning schools running at least 116 programmes. The number of programmes increased significantly since 2000, but now facing major downward pressure because of university reorganization and falling student demand. While once planning schools were predominantly stand-alone academic units with an increasing number being subsumed within broader disciplinary groupings, such as with Geography, multidisciplinary Built Environment departments or paired with Architecture, which is symptomatic of UK higher education as a whole. Each planning school has a differing research and teaching ethos, mix of full-time or part-time staff, career academics and practice-based staff. Recent trends in student numbers note an increasing internationalization of the student body, with nearly $26 \%$ from non-European countries, $53 \%$ were male and $48 \%$ were studying on postgraduate courses.

\footnotetext{
${ }^{4}$ http://www.thestudentsurvey.com/
} 
Drawing on a major survey completed for the RTPI in 20095, Ellis et al (2010) captured a picture of contemporary planning schools, producing comprehensive data on the planning academic staff for the first time. Although these findings can only be summarized here, Ellis et al found that the planning academy was a very diverse body, broadly representative (in terms of gender and ethnicity) of the population as a whole and reflecting the makeup of the student body. This also showed how the planning academy had changed substantially in recent years in terms of entry qualifications and experience, becoming more international and with more women being employed, although issues in terms of equality at higher grades remain. The survey found that only $54 \%$ of academics were members of the RTPI, $58 \%$ have a professional planning qualification and $71 \%$ have some form of practice experience. However, professional membership is heavily biased towards the older cohort of staff, who are due to retire in the next 5-10 years. The survey highlighted that $67 \%$ of academics are engaged in research, teaching and administration, with an expectation that they should perform at a high level in these areas, with the result that extra-mural activities, covering many valuable aspects of the academy-professional relationship are given a low institutional priority. Although space restricts wider discussion of the survey, Figure 4 highlights the ways in which planning academic see their key role - with professionalism and teaching still being dominant identities.

\section{Figure 4: How far do you agree with the following statements as a description of how you} see yourself in relation to your work?

I see myself as a university administrator or manager

I see myself as a scholarly researcher with no specific disciplinary identity

I see myself as a as an expert of another discipline (geography, law, sociology etc), making an effective contribution to the field of planning researcher

I see myself as higher education teacher

I see myself as a professional planner

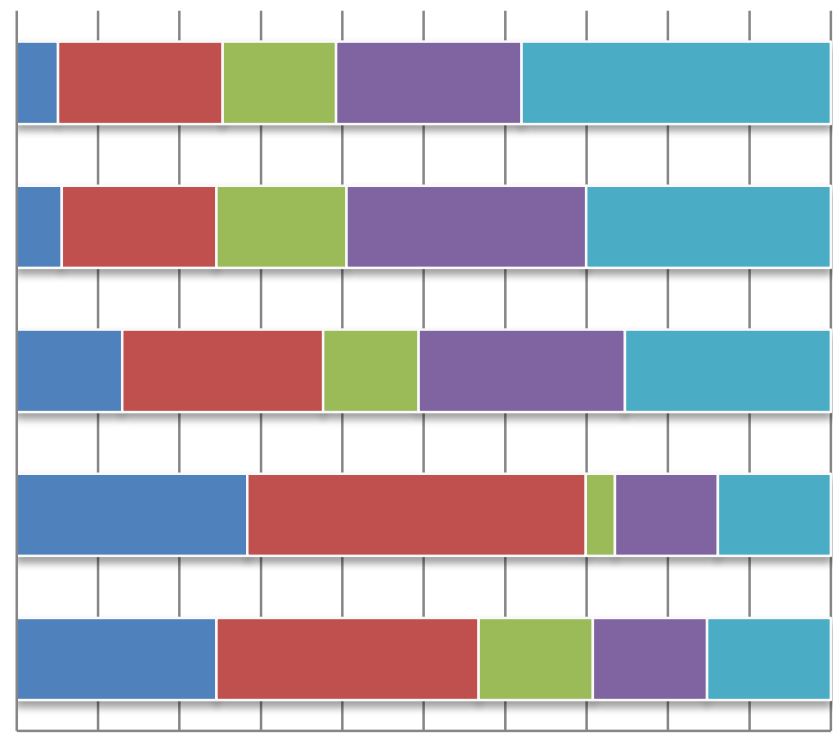

$\begin{array}{llllllllllll}0 \% & 10 \% & 20 \% & 30 \% & 40 \% & 50 \% & 60 \% & 70 \% & 80 \% & 90 \% & 100 \%\end{array}$

- Strongly Agree $\quad$ Agree $\quad$ Neither Agree or Disagree $\quad$ Disagree $\quad$ Strongly Disagree

The work of Ellis et al also highlights the variety of staff and configurations within UK planning schools with each balancing different pressures according to size, staff and student profile and institutional setting. This showed that the average number of staff in a UK planning school is 20.4 , with $50 \%$ of schools having less than 16 staff. They do however, vary substantially in their size, outlook and institutional context. 13 are in pre-1992 universities and 14 in post-1992 universities and only $25 \%$ are in standalone departments. Using this survey Ellis et al (2010) suggest that these can be understood in terms of four different clusters ${ }^{6}$ as shown in Figure 5 , shown against two key axes. One axis indicates the tension between research-orientated compared to a professional, or practice orientation to teaching while the other highlights the degree of engagement with the planning profession, for example through levels of staff activity, qualifications and links to local practitioners.

\footnotetext{
${ }^{5}$ This consisted of a comprehensive census of planning schools, interviews (n. 12). Focus groups (n.4) and surveys of current academics (n.211) and practitioners (n.1525).

${ }^{6}$ This analysis was undertaken by taking a range of independent variables from the survey and testing them, using SPSS software to achieve the greatest variance in the data. 27 variables were chosen which cumulatively explain $63.2 \%$ variance in the data. \% of variance was Factor 1 (22\%), Factor 2 (18\%), Factor 3 (13\%), Factor $4(9 \%)$.
} 


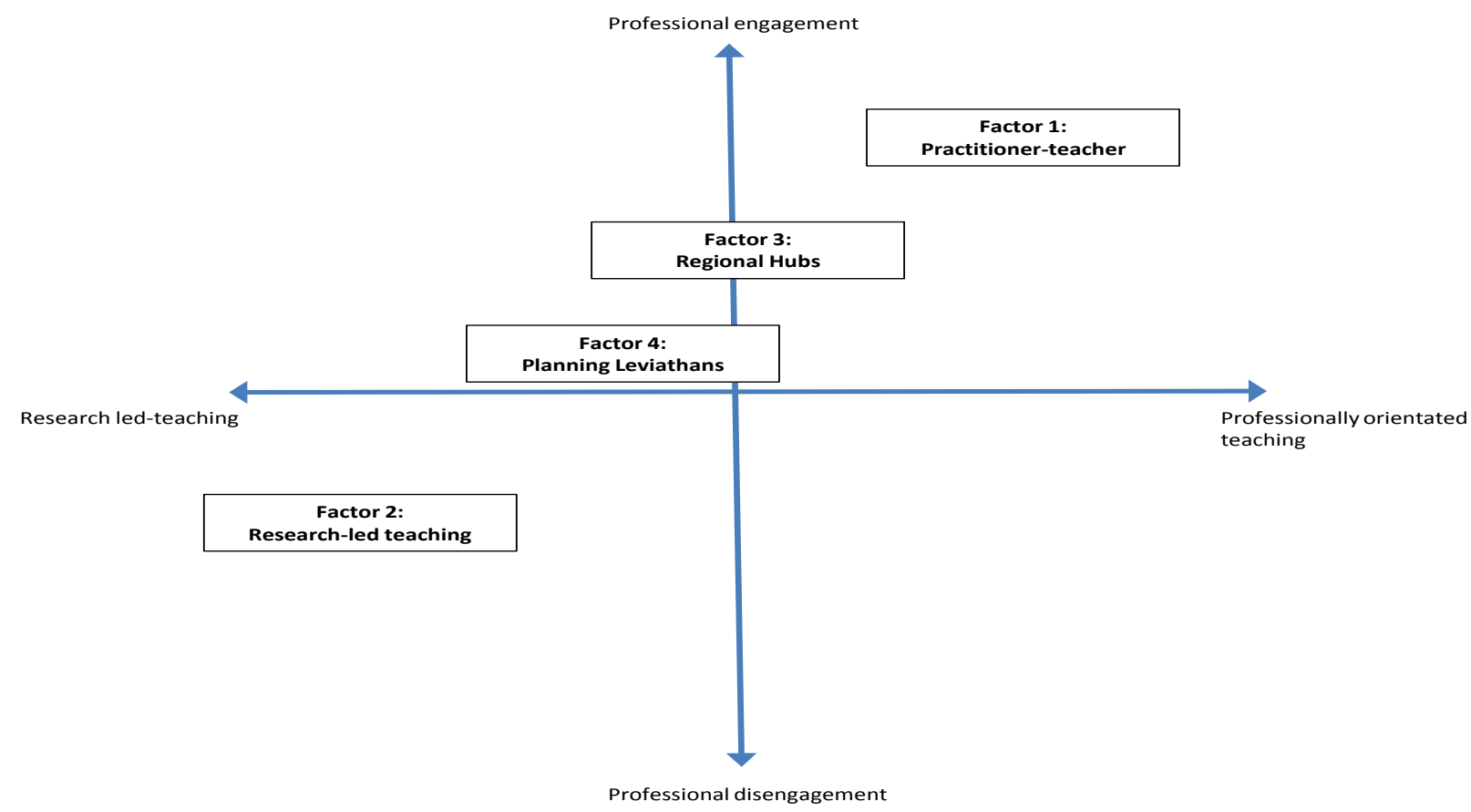

Factor 1: "Practitioner-teacher" schools. These schools tend to be located in post-1992 universities with large student cohorts and with a large majority (70\%) of staff having a planning qualification and practitioner experience. They employ a higher proportion of teaching only and part-time staff, with less of an international background and most staff are over 50 years of age. These schools appear to be focussed on professional education rather than research performance.

Factor 2: "Research-led teaching" schools. These schools are mostly located in Russell Group universities and in the top $50 \%$ of best research performers and with an emphasis on post-graduate education, particularly PhDs. The schools have a relatively young, international staff profile, encouraging appointment of those with $\mathrm{PhDs}$ and strong research records.

Factor 3: "Regional Hub" schools. These tend to be located in regionally based universities, with many having a long tradition of acting as important hubs for planning education and research. Most have large undergraduate courses and average -high research ranking, with PhD and research record being the top recruitment criteria, although Heads of Schools are concerned about their ability to recruit adequately qualified staff.

Factor 4: "Planning Leviathan" schools. These are the largest planning schools in the UK in terms of their staff, student numbers and budget, located in both pre- and post- 1992 institutions. These are characterised by a high research performance coupled with large scale educational provision at undergraduate and post-graduate levels. The staff in these schools have the lowest proportion with professional experience, planning qualifications or membership of the RTPI and a younger staff profile.

This typology is useful to the argument made in this paper for a number of reasons. First it provides a useful illustration of the variety of UK planning schools, highlighting some of the key variables that explain the differences in function and outlook. Second, from this simple discussion it can be understood that there may well be significant differences in the student experience and the types of skills developed by students at these different types of institutions, prompting reflection on the variety of learning experiences. Finally, the type of school may influence the type of relationship it has with the professional body and to consider which of these types is likely to produce the type of planners that best fits the normative model of a professional panel now needed in practice. Given the various pressures now facing many planning schools, it also focusses the mind on considering which of these type of schools can best weather current upheavals in universities and planning 
education, to ensure that a steady supply of planning graduates can be maintained to meet continuing demand. One can speculate that given the forces of completion for student recruitment, professional engagement would become an aspiration to enhance graduate employability while internal forces within universities force continual improvement in research performance, which brings significant financial rewards, attracts higher quality staff and accretes the status of the academic unit. Furthermore, high institutional status appears to be a key driver of international student recruitment.

Thus would therefore suggest that, while respecting specific institutional traditions and characteristics, the normative future model for UK planning schools (and perhaps internationally) is one which displays both high quality research and is professionally engaged, i.e. tending to the top left corner of Figure 5, an area currently not occupied by many UK planning schools. Such an aspiration offers a range of advantages to both planning schools and is arguably of more value to the profession as a learned body of practitioners.

One can speculate therefore that each of the types of UK planning schools need to adopt a range of strategies to achieve such advantages, as schematically shown in Figure 6. Space does not permit a detailed exploration of these strategies, but the final section examines to role of further aligning teaching with research to help achieve such an orientation.

Figure 6: Normative strategies for UK planning schools

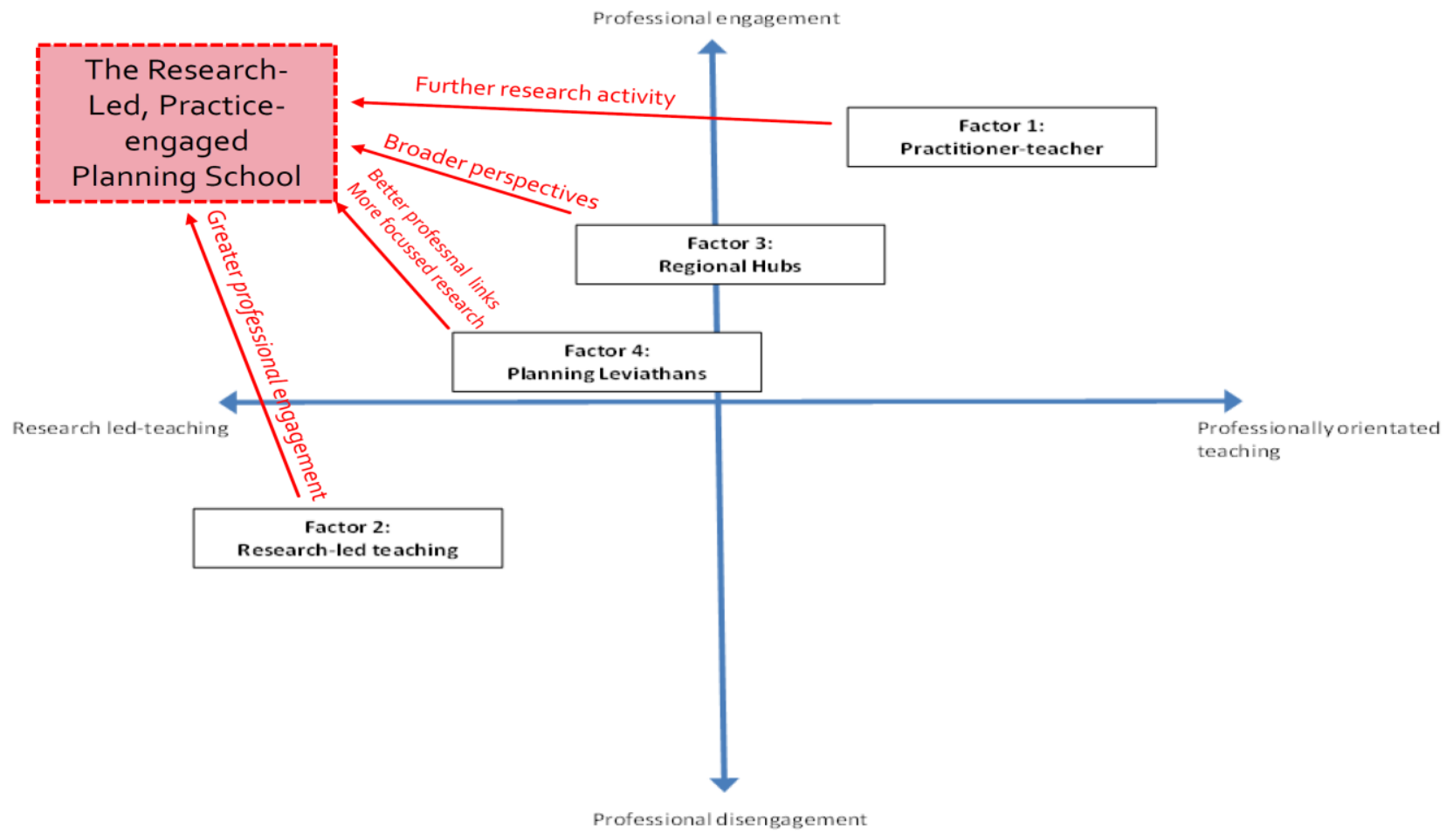

\section{Research-led, practice-engaged teaching}

It is therefore useful to consider the implications this changing context for planning education and to consider what this may mean for future relationships between planning schools and the professional body, how the student experience and educational quality can be enhanced and how the intense research activity being undertaken in UK planning schools can be exploited for the practice of planning.

We should recognise that Universities make a critical contribution to the place-making strategies of host cities and within this context complex and multi-layered relationships (Addie et al 2014) and as an applied discipline can make a significant 'impact', (acknowledging the ambiguous nature of the concept of impact - see Haughton et al 2013. Marx and Feathers, 2014). Indeed, Griffiths (2004) has noted that applied fields such as planning 
have a distinct approach to knowledge generation in that "they are orientated not towards knowledge and understanding for their own sake, but towards the use of knowledge and understanding in addressing conflicts, tackling problems and meeting needs of clients or other groups' often complex and negotiating these can bring benefits themselves.' (p.715). This therefore offers substantial potential for levering benefits of knowledge production for both students and the wider profession, through research led-teaching, practice-engaged teaching that tracks the normative strategies mapped on Figure 6 and can play a key role in establishing synergies between universities and professions (Griffiths 2004).

There been extensive debates on the nature and benefits of research-led teaching, recognising that it is interlinked with strategies of Inquiry based learning (Spronken-Smith and Walker 2010) or problem based learning (Schmidt et al 2011). Indeed, while the research-teaching nexus has a wide range of dimensions and interpretations (Healey, 2005) and indeed myths attached to it (Brew 2010), one can conceive it operating around two key axis, as shown in Figure 7, that reflect the fact that this can consist of research-led, research orientated, research based or research informed approaches (Griffiths 2004, p.722).

Figure 7: Curriculum design and the research teaching nexus (from Healey 2005)

\begin{tabular}{|c|c|c|c|}
\hline \multicolumn{4}{|c|}{ STUDENT-FOCUSED } \\
\hline \multicolumn{4}{|c|}{ STUDENTS AS PARTICIPANTS } \\
\hline \multirow{4}{*}{$\begin{array}{l}\text { EMPHASIS ON } \\
\text { RESEARCH } \\
\text { CONTENT }\end{array}$} & Research-tutored & \multirow{2}{*}{$\begin{array}{l}\text { Research-based } \\
\text { Curriculum emphasises } \\
\text { students undertaking } \\
\text { inquiry-based learning }\end{array}$} & \multirow{4}{*}{$\begin{array}{l}\text { EMPHASIS ON } \\
\text { RESEARCH } \\
\text { PROCESSES } \\
\text { AND } \\
\text { PROBLEMS }\end{array}$} \\
\hline & $\begin{array}{l}\text { Curriculum emphasises } \\
\text { learning focused on } \\
\text { students writing and } \\
\text { discussing papers or } \\
\text { essays }\end{array}$ & & \\
\hline & Research-led & Research-oriented & \\
\hline & $\begin{array}{l}\text { Curriculum is structured } \\
\text { around teaching subject } \\
\text { content }\end{array}$ & $\begin{array}{l}\text { Curriculum emphasises } \\
\text { teaching processes of } \\
\text { knowledge construction } \\
\text { in the subject }\end{array}$ & \\
\hline \multicolumn{4}{|c|}{ TEACHER-FOCUSED } \\
\hline \multicolumn{4}{|c|}{ STUDENTS AS AUDIENCE } \\
\hline
\end{tabular}

An emphasis on research focussed teaching can be frustrated by wider university structures pedagogical practices and assumptions about what students are capable of (Brew, 2010) and there are specific challenges in accredited subjects like planning as professional bodies tend to encourage 'curriculum creep' and in so doing further distance research and teaching (Healey 2005)

However, there is substantial evidence that highlights the benefits of integrating research and teaching. For example, it encourages students to take more control and independence over their studies. Built into much planning education. Seymour et al (2004) report that undergraduate involved in research projects have increased confidence, better problem solving skills an critical thinking, greater confidence helps clarify career goals and transferable skills. It has been suggested that research-led teaching can create a more engaging curriculum that allows students to better understand research and to know how to base decisions on evidence, collected in a robust way. In this way students do not become just the 'masters of bodies of thought' but they can cope with the challenge of open critical inquiry. As future users of research, embedding this more effectively 
in the curriculum also allows them to think more critically about some of the challenges they would face when in planning practice and thus enhancing their employability of students.

This approach can therefore help overcome the growing divide between research and teaching that is emerging in UK planning schools, address student engagement and could help encourage and reward scholarship in teaching. However, there is also a need to consider the type of research that can have the greatest impact on planning thought and practice, which is not just a role for the academy but also for the profession well to stimulate this through recognising the value of university research, rewarding excellence, disseminating research findings in ways that make most sense, develop ways to stimulate policy-relevant research and getting practicing planners to taken an interest and use such research (see Ellis et al for further discussion). One would expect that better engagement with robust evidence and would also stimulate further innovation in planning practice.

We know however, that planning education - in almost every country - has had a strong tradition of action research and engaging students on consultancy-like projects with planning authorities and communities. Here we are calling reflecting on this tradition and going further in the generation of new knowledge, rather than the application of existing knowledge. This could be done in the context of a whole range of activity including gathering pilot data for a research grant applications, exploring different or innovative research techniques, developing online resources, testing the robustness of secondary data or involvement in problem-focussed action research projects. Indeed, we must never overlook the value of this type of activity, both to developing more robust research findings, but also in the value it can bring planning stakeholders who often do not have access to resources to be able to try higher risk research activities or in some cases, more incisive data monitoring. As noted in Figure 6, progressing this agenda will have different implications for each 'type' of planning school, with some having to enhance their research activity, others to better engage practitioners in their research some to engage in research questions beyond their immediate locale. The key message here, is the need to further embed the ideal of research-led, practitioner engaged teaching as a normative goal for planning education.

\section{Conclusions}

This paper has reviewed the evolution and current challenges to planning education in the UK. It has briefly described how planning's claims to professional status partly depends on the higher learned activities, which largely emanate from universities. While there has traditionally been a close relationship between universities and the planning profession, in recent years there have been increased issues of tension between planning schools subject to a variety of external pressures and the planning profession. There are broad concerns about the future direction of planning education in the UK related to the viability of planning schools as distinct academic units and the engagement of student taking planning courses. Although not offered as a panacea and only briefly described here, it is suggested that a focus on research-led, practitioner engaged teaching offers a way of addressing some of the priorities of UK planning education. 


\section{References}

Addie, J. P. D., Keil, R., \& Olds, K. (2014). Beyond Town and Gown: Universities, Territoriality and the Mobilization of New Urban Structures in Canada. Territory, Politics, Governance, (ahead-of-print), 1-24.

Barker, Kate (2006) Barker Review of Land Use Planning: Final Report - Recommendations.

Brew, A. (2010) "Imperatives and challenges in integrating teaching and research" Higher Education Research \& Development, 29(2), 139-150.

Campbell, H. (2005) „Reflexivity and the Planning Academic: Challenges and Responsibilities", Planning Theory and Practice, Vol. 6. No. 2, pp. 235-237.

Cherry, G. (1974) The Evolution of British Town Planning, Leighton Buzzard, Leonard Hill.

Cockurn, C. (1970) The provision of planning education, Centre for Environmental Studies, Bristol.

Community of Practice?', Planning Practice \& Research 19(4): 435-446

Dalton, L. C. (2007) 'Preparing Planners for the Breadth of Practice', Journal of the American Planning Association 73(1): $35-48$

Dalton, L.C. (2001) 'Weaving the Fabric of Planning as Education', Journal of Planning Education and Research, 20(4), pp. 423-436

Davoudi, S., \& Pendlebury, J. (2010) “Centenary paper: The evolution of planning as an academic discipline" Town Planning Review, 81(6), 613-646.

Durning, B. (2004) 'Planning Academics and Planning Practitioners: Two Tribes or a or a Community of Practice?", Planning Practice \& Research, Vol. 19, No. 4, pp.435-446

Ellis, G. Murtagh, B and Copeland L. (2010) The Future of the Planning Academy, RTPI, London. Available at: http://www.rtpi.org.uk/briefing-room/news-releases/2011/january/rtpi-report-highlights-importance-of-links-betweenplanning,-education,-research-and-practice/

Evans, B. (1993) "Why We No Longer Need a Planning Profession", Planning Practice and Research, Vol. 8, No. 1, pp. 915.

Evans, B. and Rydin, Y. (1997) “Planning, Professionalism and Sustainability", in Evans, B. and Blowers, A. (eds) Town Planning Into the 21st Century, London, Routledge.

Frank, A. I. (2006) “Three decades of thought on planning education" Journal of Planning Literature, 21(1), 15-67.

Frank, A. I., Mironowicz, I., Lourenço, J., Franchini, T., Ache, P., Finka, M., and Grams, A. (2014) “Educating planners in Europe: A review of 21st century study programmes". Progress in Planning, 91, 30-94.

Goodstadt, V. (2005) "Rebuilding the Planning Community: Questioning the Orthodoxy and Speaking the Truth", Planning Theory and Practice, Vol. 6, No. 2, pp. 247- 249.

Grant, M. (1999) "Planning as a Learned Profession", paper prepared for the Royal Town Planning Institute.

Griffiths, R. (2004) "Knowledge production and the research-teaching nexus: The case of the built environment disciplines" Studies in Higher Education, 29(6), 709-726.

Gurran, N., Norman, B. and Gleeson, B. (2008) Planning Education Discussion Paper, Prepared for the Planning Institute of Australia, PIA.

Haughton, G., Deas, I., \& Hincks, S. (2014). “Making an impact: when agglomeration boosterism meets antiplanning rhetoric" Environment and Planning A, 46(2), 265-270. 
Healey, M. (2005) 'Linking research and teaching: exploring disciplinary spaces and the role of inquiry-based learning', in In Barnett, R (ed) (2005) Reshaping the University: New Relationships between Research, Scholarship and Teaching. McGraw Hill / Open University Press, pp.67-78

Healey, P. (1983) "British Planning Education in the 1970s and 1980s" in Davies, H.W.E. and Healey, P., British Planning practice and Planning Education in the 1970s and 1980s, Working Paper No. 70, Oxford Polytechnic Department of Town Planning, Oxford.

Healey, P. (1985) 'The professionalization of planning in Britain', Town Planning Review, Vol. 56

higher education in a changing policy context in England', CEBE Transactions, Vol. 2, No., 2, pp. 48-62.

Judge, E. And Haughton, G. (1998) "The UK Research Assessment Exercise and Planning: The Promotion of Irrelevance to the Real World?" Planning Practice and Research, Vol. 13, No.1, pp 9-12.

Marx, G., \& Feathers, H. (2014) “Making an impact: misreading, misunderstanding, and misrepresenting research does nothing to improve the quality of public debate and policy making". Environment and Planning A, 46, $2276-2282$.

Poxon, J. (2001) "Shaping the planning profession of the future; the role of planning education", Environment and Planning B: Planning and Design, Vol. 28, pp.563-580.

Punter, J. and Campbell, H. (2009) "Reflections on the 2008 United Kingdom Research Assessment Exercise for Town and Country Planning and closely associated disciplines", Town Planning Review, Vol. 80, No. 31-54.

Reade, E. (1987) British Town and Country Planning, Milton Keynes, Open University Press.

Royal Town Planning Institute (2001) A New Vision for Planning, London, RTPI.

Royal Town Planning Institute (2003) Education Commission Report, London, RTPI.

Schmidt, H. G., Rotgans, J. I., \& Yew, E. H. (2011). The process of problem-based learning: what works and why. Medical education, 45(8), 792-806.

Schuster, G. (1950) Report of the Committee on Qualifications of Planners, Cmd 8059, London, HMSO.

Seymour, E., Hunter, A. B., Laursen, S. L., \& DeAntoni, T. (2004). Establishing the benefits of research experiences for undergraduates in the sciences: First findings from a three-year study. Science Education, 88(4), 493-534.

Spronken-Smith, R., \& Walker, R. (2010) Can inquiry-based learning strengthen the links between teaching and disciplinary research?. Studies in Higher Education, 35(6), 723-740.

Thomas, A. H. (1979) An Analysis of Changes in Planning Education, University College, London. Unpublished M.Phil Thesis.

Thomas, A.H and Thomas, W.K. (1981) Planning Education in the 1970s, Working Paper No. 65, Oxford Polytechnic, Department of Town Planning, Oxford.

Thomas, H. (2005) Pressures, Purpose and Collegiality in UK Planning Education", Planning Theory and Practice, Vol. 6, No.2, pp. 238- 247. 